\title{
Medial sphenoid ridge meningiomas: early and long-term results of surgical removal using the fronto-temporo-orbito-zygomatic approach
}

\section{Bezpośrednie i odległe wyniki leczenia chirurgicznego oponiaków przyśrodkowej części skrzydła mniejszego kości klinowej z wykorzystaniem dostępu czołowo-skroniowo-oczodołowo-jarzmowego}

Piotr tadziński, Henryk Majchrzak, Wojciech Kaspera, Krzysztof Majchrzak, Michał Tymowski, Piotr Adamczyk

Katedra i Oddział Kliniczny Neurochirurgii, Śląski Uniwersytet Medyczny, Sosnowiec

Neurologia i Neurochirurgia Polska 2010; 44, 5: 464-474

\begin{abstract}
Background and purpose: The fronto-temporo-orbitozygomatic approach (FTOZA) is an alternative to the pterional approach in surgical resection of meningiomas of the medial part of the lesser wing of the sphenoid bone. The purpose of this study is to present our results of treatment of these meningiomas using the FTOZA.

Material and methods: Thirty patients (19 women, 11 men) with a central skull base tumour were included in the study. The neurological status of the patients was assessed before and after surgery as well as at the conclusion of treatment. The approximate volume of the operated tumour, its relation to large blood vessels, cranial nerves and brainstem, as well as consistency and vascularisation were assessed.

Results: The symptom duration ranged from 1 to 36 months (median: 6 months). Impaired visual acuity was the predominant symptom in $27.5 \%$ of patients. Less frequent symptoms included paresis/paralysis of the third cranial nerve, headache, psychoorganic syndrome and epilepsy. Approximate volume of the tumours ranged from 5 to $212 \mathrm{~mL}$ (median: $63 \mathrm{~mL}$ ). Total or subtotal resection was achieved in $77 \%$ of patients. The postoperative performance status improved in $16.5 \%$, did not change in $52.8 \%$ and deteriorated in $26.4 \%$ of patients. One $(3.3 \%)$ patient died after the surgery.
\end{abstract}

\section{Streszczenie}

Wstęp i cel pracy: Dostęp czołowo-skroniowo-oczodołowo-jarzmowy (DCSOJ) jest alternatywą dla dostępu pterionalnego w operacyjnym leczeniu oponiaków przyśrodkowej części skrzydła mniejszego kości klinowej. Celem niniejszej pracy jest przedstawienie własnych wyników leczenia powyższych oponiaków z wykorzystaniem DCSOJ.

Materiał i metody: Analizie poddano grupę 30 chorych z guzami centralnej części podstawy czaszki, wśród których było 19 kobiet i 11 mężczyzn. Ocenie podlegał stan neurologiczny chorych przed rozpoczęciem leczenia, po operacji i po zakończeniu leczenia oraz zmiany ich aktywności życiowej. Określano przybliżoną objętość operowanych guzów, ich stosunek do dużych naczyń, nerwów czaszkowych i pnia mózgu, jak również konsystencję i stopień unaczynienia.

Wyniki: Długość wywiadu wahała się od 1 do 36 miesięcy (mediana: 6 miesięcy). W 27,5\% przypadków wiodącym objawem były zaburzenia ostrości wzroku. Rzadziej występowały niedowład lub porażenie nerwu okoruchowego, bóle głowy, zespół psychoorganiczny i padaczka. Przybliżona objętość usuniętych guzów wahała się od 5 do $212 \mathrm{~cm}^{3}$ (mediana: $63 \mathrm{~cm}^{3}$ ). W 77\% przypadków przeprowadzone resekcje były doszczętne lub z niewielkimi pozostałościami guzów. Aktywność życiowa leczonych w $16,5 \%$ uległa poprawie, w 52,8\%

Correspondence address: dr hab. med. Piotr kadziński, Katedra i Oddział Kliniczny Neurochirurgii, Śląski Uniwersytet Medyczny w Katowicach, Wojewódzki Szpital Specjalistyczny nr 5 im. św. Barbary, Pl. Medyków 1, 41-200 Sosnowiec, phone +32 36820 24, fax +32 3682550 , e-mail:sekr_nch@wss5.pl

Received: 12.02.2010; accepted: 25.06.2010 
Conclusions: The FTOZA is a useful technique for removal of tumours expanding superiorly to the middle cranial fossa base without significant compression of the brain. Ability to remove tumours through the described approach decreases as the degree of infiltration of the clivus increases.

Key words: sphenoid bone, internal carotid artery, meningioma, microsurgery, skull base surgery.

\section{Introduction}

The fronto-temporo-orbito-zygomatic approach (FTOZA) is an extension of a classic pterional approach that includes osteotomy which encompasses the superolateral orbital rim, superior part of the body of the zygomatic bone and zygomatic arch. This approach facilitates access to the middle cranial fossa and adjacent regions through reduction of the distance between the surgeon and the operative field along with a decrease of necessary brain retraction. On top of that, FTOZA improves the range of manipulation above the skull base level, in particular within the interpeduncular fossa. The indications for this approach in oncology as well as in the treatment of vascular malformations arise from its advantages then. The aim of the following paper is to present our results of the surgical treatment of middle sphenoid ridge meningiomas using the FTOZA.

\section{Material and methods}

FTOZA has been used in the Clinical Department of Neurosurgery in Sosnowiec since 1990. During the first three years it was used solely in the treatment of vascular malformations. It has been used for oncological indications since 1993. A retrospective analysis of 30 patients (19 women, 11 men aged 19 to 71 years) treated for various types of middle sphenoid ridge meningiomas was performed. Additionally to the aforementioned group of meningiomas, FTOZA was used by the authors to take out two meningiomas that involved the temporal pyramid apex and upper part of the clivus and seven tumours of the central part of the skull base, including haemangiopericytomas, epidermoids, chordomas and pituitary adenomas. Due to their variability, these cases were not included in the presented clinical analysis.

Neurological status of the patients at the beginning of the treatment, at discharge and at the end of rehabi- nie zmieniła się, w 26,4\% nastąpit jej spadek, 3,3\% leczonych zmarło.

Wnioski: Dostęp czołowo-skroniowo-oczodołowo-jarzmowy stanowi dogodną drogę usuwania guzów nowotworowych rozrastających się ku górze z centralnej części podstawy środkowego dołu czaszki i obszarów sąsiadujących, bez konieczności wywierania znacznego ucisku na mózg. Możliwości usuwania guzów z omawianego dostępu maleją wraz z ich rozrostem wzdłuż stoku.

Słowa kluczowe: kość klinowa, tętnica szyjna wewnętrzna, oponiak, mikrochirurgia, chirurgia podstawy czaszki.

litation (Table 1 and 2) and changes in everyday performance assessed with the Karnofsky scale (Table 3) were analysed. The volumes of the tumours were approximated with the formula for a rotational ellipsoid (volume $=\Pi / 6(x \times y \times z))$, based on MRI examination. The extent of resection was assessed based on preand postoperative MRI examinations; the Simpson scale was used as well. The relationship to large vessels, cranial nerves and brain stem along with tumour consistency and vascularity was also evaluated. The distribution of catamnesis time, follow-up time and tumour volumes was analysed with the Shapiro-Wilk test. Variables without normal distribution were described with median and interquartile range (IQR). Variables with normal distribution were described with mean and standard deviation (SD).

\section{Results}

The time of catamnesis for all the patients varied from 1 to 36 months (median: 6 months, IQR: 4-12 months). Unilateral or bilateral optic nerve abnormalities were the presenting symptom in $27.5 \%$. This symptom was the earliest and the most common one. Approximately $20 \%$ of cases presented with headache, epilepsy, psychoorganic syndrome and paresis or paralysis of the oculomotor nerve. Other, less frequent signs and symptoms are summarized in Table 1.

Tumours were usually located in eight adjacent anatomical regions: median part of the lesser sphenoid wing (33.3\%), tentorial incisura (20\%), median part of the larger sphenoid wing (26.6\%), lateral boundaries of the cavernous sinus (20\%), interior of the cavernous sinus $(23.3 \%)$, sellar region (16.6\%), interpeduncular fossa $(33.3 \%)$ and upper part of the clivus $(20 \%)$. Approximate volumes of the tumours varied from 5 to $212 \mathrm{~cm}^{3}$ (median: $63 \mathrm{~cm}^{3}$, IQR: 24-87 $\mathrm{cm}^{3}$ ). 
Tumours were adjacent to the brain stem in $60 \%$ of cases; however, they displaced it in only $13.3 \%$ of cases. In two cases, brain stem pia infiltration was encountered. Tumours adjoined cranial nerves (olfactory, optic, oculomotor, trochlear, trigeminal or abducent) in $83.3 \%$ of cases. Adhesions or encasement of cranial nerves resulted in technical difficulties in nerve continuity preservation. Adhesions were common in the case of the optic nerve while the oculomotor nerve was usually encased, most often in meningiomas that infiltrated the cavernous sinus (23.3\% of cases). Similarly, $83.3 \%$ of tumours were adjacent to large vessels, i.e. internal carotid artery, basilar artery and/or their branches. In four cases, arachnoid that surrounded vessels was infiltrated; the internal carotid artery was involved in three cases and the middle cerebral artery was involved in one case.

Table 1. Neurological abnormalities present before treatment (29 cases)

\begin{tabular}{|lccc|}
\hline Neurological abnormality & $\begin{array}{c}\text { Examination on } \\
\text { admission (\%) }\end{array}$ & $\begin{array}{c}\text { Examination on } \\
\text { discharge (\%) }\end{array}$ & $\begin{array}{c}\text { Follow-up } \\
\text { examination (\%) }\end{array}$ \\
\hline Headache & 20.6 & 0 & 0 \\
\hline Optic nerve abnormalities & 27.5 & 17.2 & 13.7 \\
\hline Third nerve palsy or paresis & 24.1 & 20.6 & 13.7 \\
\hline Fourth nerve palsy or paresis & 3.4 & 3.4 & 3.4 \\
\hline Sixth nerve palsy or paresis & 3.4 & 3.4 & 3.4 \\
\hline Decreased sensation in distribution of ophthalmic nerve & 3.4 & 3.4 & 3.4 \\
\hline Decreased sensation in distribution of maxillary nerve & 3.4 & 3.4 & 3.4 \\
\hline Maxillary nerve neuralgia & 6.8 & 0 & 0 \\
\hline Mandibular nerve neuralgia & 3.4 & 0 & 3.4 \\
\hline Hemiparesis & 6.8 & 3.4 & 13.7 \\
\hline Epilepsy & 20.6 & 20.6 & 3.4 \\
\hline Psychoorganic syndrome & 17 & 6.8 & 3.4 \\
\hline Aphasia & 3.4 & 3.4 & 0 \\
\hline
\end{tabular}

Table 2. Changes in neurological status which occurred after surgical treatment (29 cases)

\begin{tabular}{|lccc|}
\hline Neurological abnormality & $\begin{array}{c}\text { Examination on } \\
\text { admission (\%) }\end{array}$ & $\begin{array}{c}\text { Examination on } \\
\text { discharge (\%) }\end{array}$ & $\begin{array}{c}\text { Follow-up } \\
\text { examination (\%) }\end{array}$ \\
\hline Rhinorrhea & 6.8 & 0 & 0 \\
\hline Hydrocephalus & 3.4 & 0 & 0 \\
\hline Hemiparesis & 34.4 & 31 & 13.7 \\
\hline Aphasia & 17.1 & 3.4 & 3.4 \\
\hline Psychoorganic syndrome & 3.4 & 0 & 0 \\
\hline Optic nerve abnormalities & 3.4 & 27.5 & 17.1 \\
\hline Third nerve palsy or paresis & 27.5 & 13.7 & 10.3 \\
\hline Fourth nerve palsy or paresis & 13.7 & 6.8 & 3.4 \\
\hline Sixth nerve palsy or paresis & 10.3 & 3.4 & 3.4 \\
\hline Decreased sensation in distribution of maxillary nerve & 3.4 & & 0.4 \\
\hline
\end{tabular}


Cranial nerves were injured, i.e. their continuity was compromised, in $17 \%$ of cases. Postoperative cranial nerve disturbances that resulted from surgery rather than the disease itself were seen in $27.5 \%$ of patients. Follow-up revealed persistent changes in $20.5 \%$ of patients (Table 2).

In three cases, an intraoperative injury of the internal carotid artery occurred. In the first one, the damage resulted from vessel wall infiltration by the tumour. Haemostasis was achieved through temporary pressure reduction and compression of the tumour remnants along with the injury site. In another case, during coagulation of the tumour attachment on the lateral wall of the cavernous sinus, bleeding occurred that was controlled with a surgical tamponade for it was considered to be of cavernous sinus origin. The patient underwent a second operation two days later after massive intracerebral haemorrhage; the surgery revealed an internal carotid artery injury in its intracavernous part. The in jury was repaired with a vascular suture. An intracerebral clot that destroyed deep brain structures was simultaneously removed. This patient subsequently died; this was the only perioperative casualty in our cohort. The third case of intraoperative internal carotid artery injury occurred during recurrent middle sphenoid ridge meningioma surgery which required all of the intracranial parts of the internal carotid artery to be liberated from the tumour. Several minutes later, while subsequent stages of the surgery were being performed, the blood stream perforated an undermined arterial wall. A haemorrhage was initially controlled with arterial clips. Consequently, the ophthalmic artery was closed and dissected and proximal and distal dural rings of the internal carotid artery were opened. This enabled the mobilization of the whole artery, dissection of the tumour-related eroded part of the vessel and haemodynamically efficient end-to-end anastomosis. Postoperative hemiparesis with oculomotor nerve paralysis arose; it significantly subsided afterwards. The bulb did not atrophy; the eye on the tumour side was blind preoperatively. Apart from postoperative cranial nerve injuries, the most common complications included hemiparesis (34\%) and aphasia (17\%). During the follow-up, however, their prevalence decreased to $27.5 \%$ and $10 \%$, respectively.

Fifty percent of tumours were highly vascular. Preoperative angiography was performed in all of the cases where preoperative MRI suggested large vessel encasement. Preoperative embolization subsequent to angiography that revealed high vascularity was performed in one case.
Table 3. Assessment of functional capacity of patients treated with frontotemporo-orbito-zygomatic approach according to Karnofsky performance scale

\begin{tabular}{|c|c|c|c|}
\hline Patient no. & $\begin{array}{l}\text { Examination } \\
\text { on admission }\end{array}$ & $\begin{array}{l}\text { Examination } \\
\text { on discharge }\end{array}$ & $\begin{array}{c}\text { Follow-up } \\
\text { examination }\end{array}$ \\
\hline 1 & 90 & 70 & 80 \\
\hline 2 & 60 & 50 & 60 \\
\hline 3 & 80 & 70 & 80 \\
\hline 4 & 80 & 60 & 70 \\
\hline 5 & 80 & 70 & 80 \\
\hline 6 & 70 & 80 & 90 \\
\hline 7 & 80 & 80 & 80 \\
\hline 8 & 90 & 80 & 100 \\
\hline 9 & 80 & 80 & 90 \\
\hline 10 & 80 & 80 & 100 \\
\hline 11 & 80 & 60 & 60 \\
\hline 12 & 80 & 50 & 60 \\
\hline 13 & 90 & 80 & 90 \\
\hline 14 & 90 & 90 & 90 \\
\hline 15 & 80 & 50 & 70 \\
\hline 16 & 80 & deceased & - \\
\hline 17 & 70 & 70 & 70 \\
\hline 18 & 70 & 50 & 60 \\
\hline 19 & 90 & 70 & 90 \\
\hline 20 & 80 & 80 & 80 \\
\hline 21 & 80 & 80 & 90 \\
\hline 22 & 80 & 80 & 80 \\
\hline 23 & 90 & 80 & 90 \\
\hline 24 & 80 & 70 & 80 \\
\hline 25 & 90 & 90 & 90 \\
\hline 26 & 90 & 80 & 80 \\
\hline 27 & 90 & 70 & 60 \\
\hline 28 & 80 & 80 & 80 \\
\hline 29 & 80 & 80 & 80 \\
\hline 30 & 80 & 80 & 80 \\
\hline
\end{tabular}

In seven cases $(23.3 \%)$ tumour resection was not radical. It resulted either from tumour miscellanies on infiltrated vessels or from an elective renouncement of intracavernous part removal. The other option embraced patients without clinical symptoms of intracavernous tumour penetration. In one of these cases, reoperation 

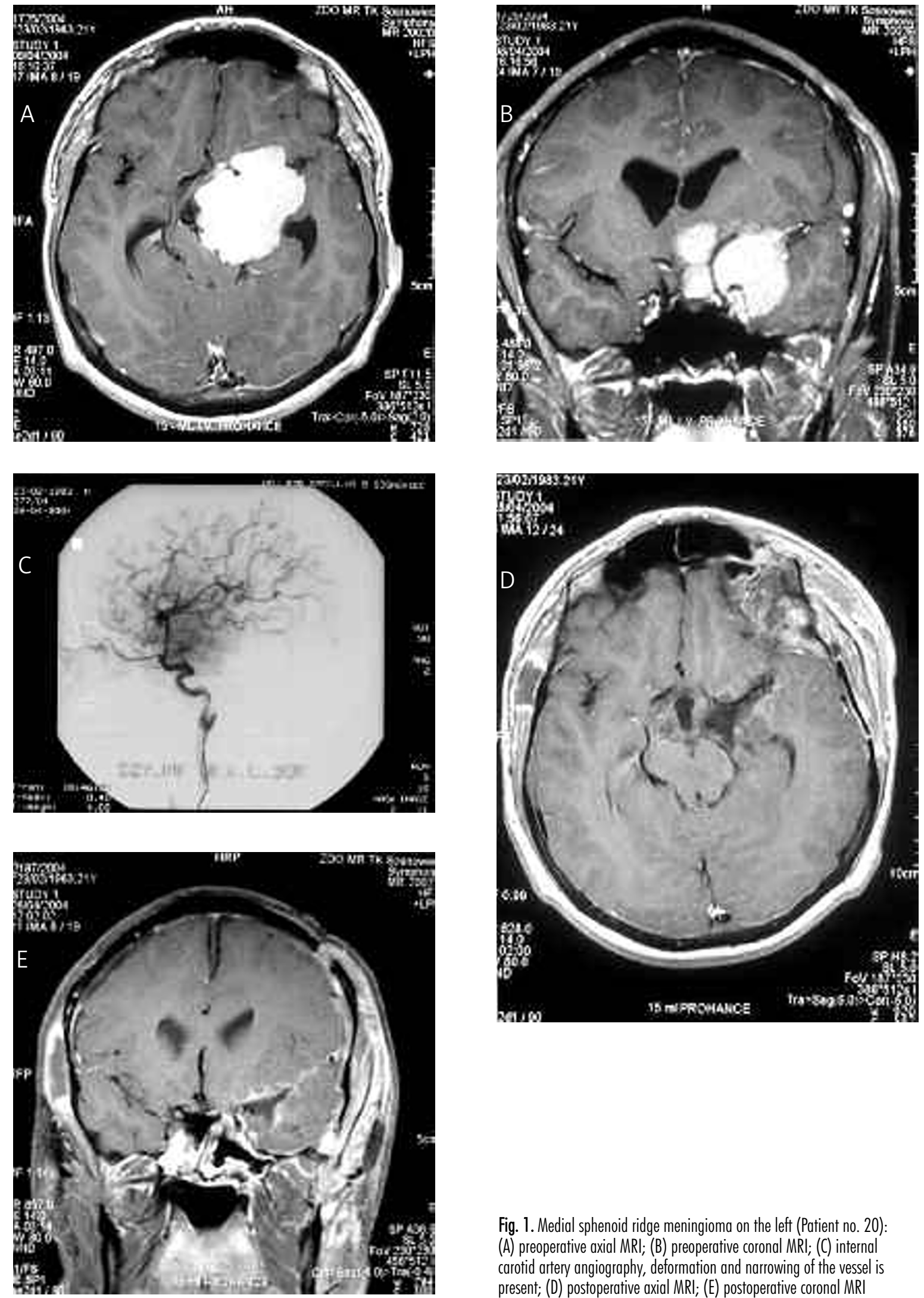

Fig. 1. Medial sphenoid ridge meningioma on the left (Patient no. 20): (A) preoperative axial MRI; (B) preoperative coronal MRI; (C) internal carotid artery angiography, deformation and narrowing of the vessel is present; (D) postoperative axial MRI; (E) postoperative coronal MRI 

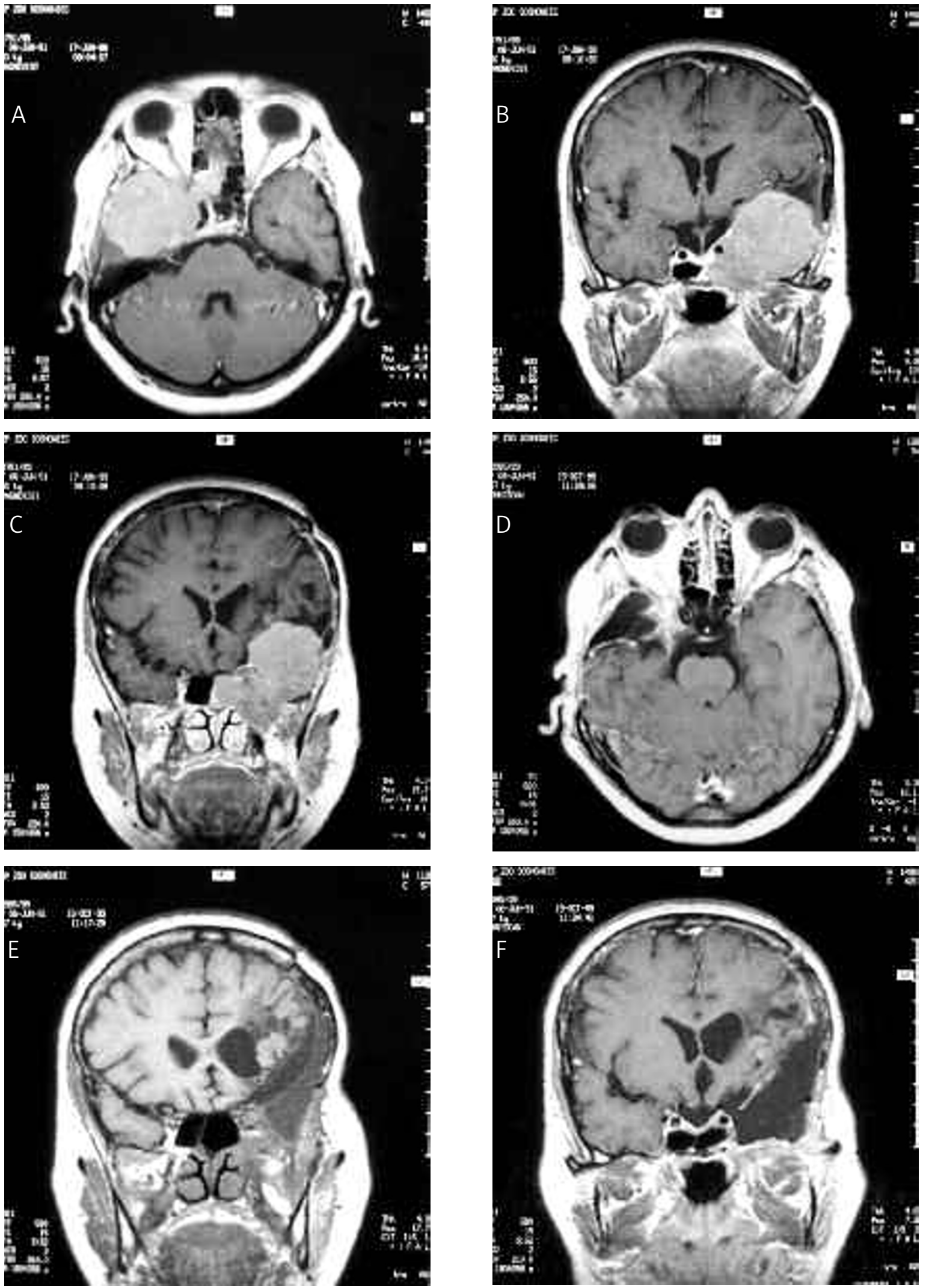

Fig. 2. Recurrent medial sphenoid ridge meningioma on the left. Tumour infiltrates cavernous sinus, cribriform plate and orbit (Patient no. 4):

(A) preoperative axial MRI; (B) preoperative coronal MRI I; (C) preoperative coronal MRI II; (D) postoperative axial MRI; (E) postoperative coronal MRI I;

(F) postoperative coronal MRI II 


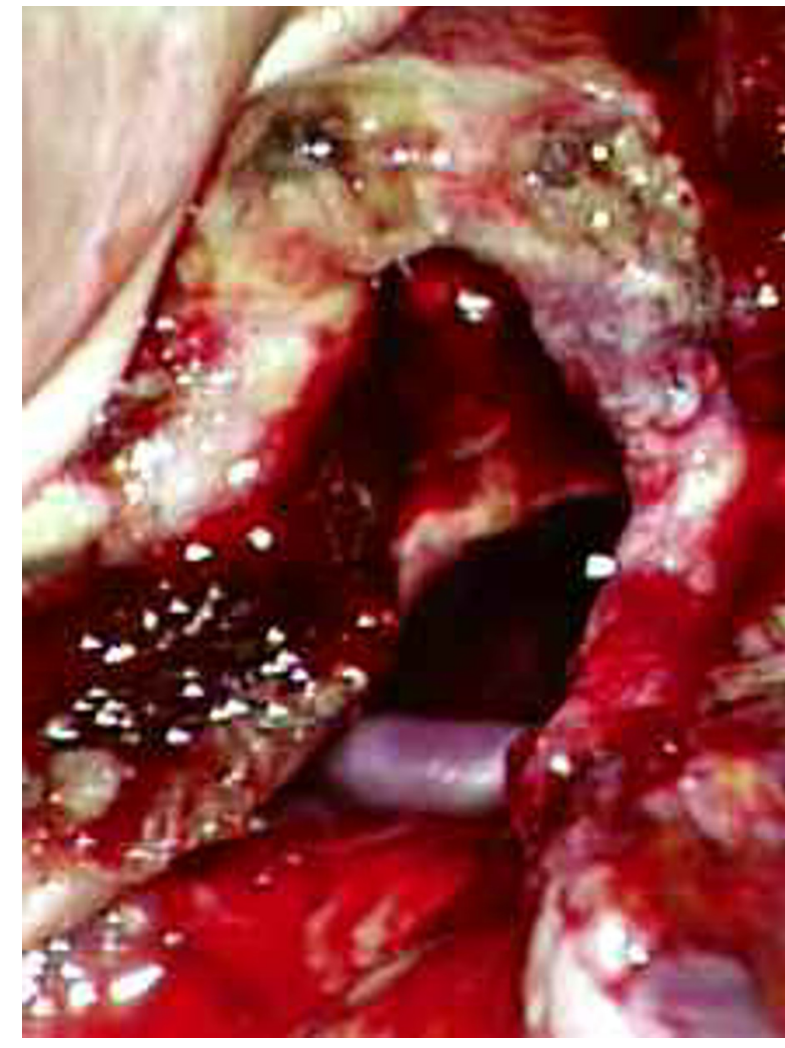

was opted for; three other patients underwent stereotactic radiosurgery. Follow-up varied from 11 to 191 months (mean: 86 months, SD: 49 months).

Comparison of the functional capacities of the patients on admission and during the follow-up as measured with the Karnofsky performance scale revealed improvement in $16.5 \%$, unchanged condition in $52.8 \%$ and deterioration in $26.5 \%$ of patients. One patient died, accounting for $3.3 \%$ in our cohort.

\section{Discussion}

Middle sphenoid ridge meningiomas, particularly large ones that expand well above skull base level and encompass the internal carotid artery with its branches, comprise the major indication for FTOZA use [1-3]. It is worth mentioning, however, that various reports still describe a pterional or frontal lateral approach in the treatment of these tumours [4-8]. In some cases, the pterional approach is expanded with resections of bone boundaries of the superior orbital fissure and optic canal [9]. An indication for FTOZA use that raises little doubt includes meningiomas that extend from the sphe-

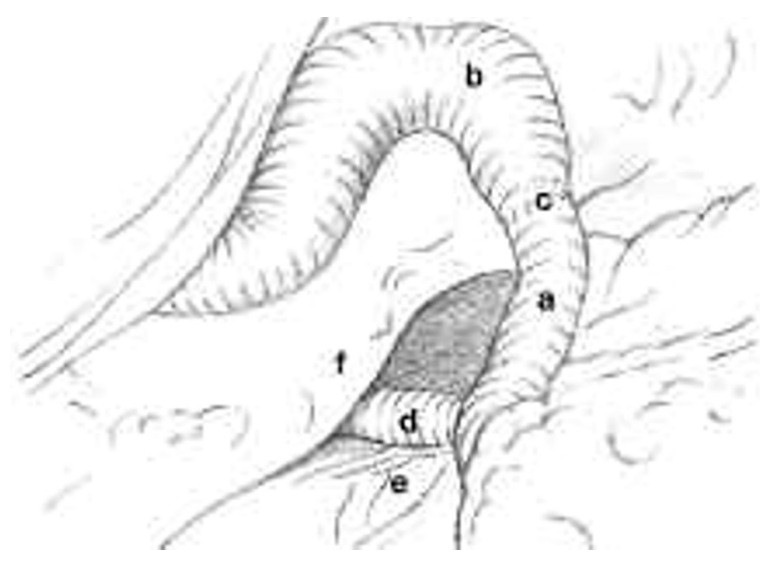

Fig. 3. Partial dissection followed by mobilization of intracavernous part and end-to-end anastomosis of the left internal carotid artery (Patient no. 4): $a$ - intradural part of the internal carotid artery, $b$ - mobilized intracarotid part of the internal carotid artery, $\mathrm{c}$ - anastomosis site, $\mathrm{d}$ - basilar artery, $e$ - brain stem, $f$ - empty cavernous sinus

noid bone via the apex of the pyramid of the temporal bone toward the upper parts of the clivus [10].

Al-Mefty $[4,11]$ describes three groups of middle sphenoid ridge meningiomas. Group I covers meningiomas with an attachment on the lower surface of the posterior clinoid process. Group II includes tumours with an attachment on the superior-lateral surface of the anterior clinoid process. Group III takes in generally small tumours with an attachment on the tip of the anterior clinoid process that penetrate the optic canal. Aside from attachment topography, Al-Mefty based his classification on tumour relation to the internal carotid artery and optic nerve. These considerations arise from an observation that the internal carotid artery is not covered by arachnoid for approximately $2 \mathrm{~mm}$ in its progress through the cavum caroticum after passing the distal ring. According to Al-Mefty, tumours which arise from the inferior surface of the anterior clinoid process directly contact the wall of the internal carotid artery and during their expansion preserve such contact with the entire intradural part of the internal carotid artery and subsequently with the middle cerebral artery. Meningiomas from group II and III, even though they encase large vessels, still retain an arachnoid layer in between; 

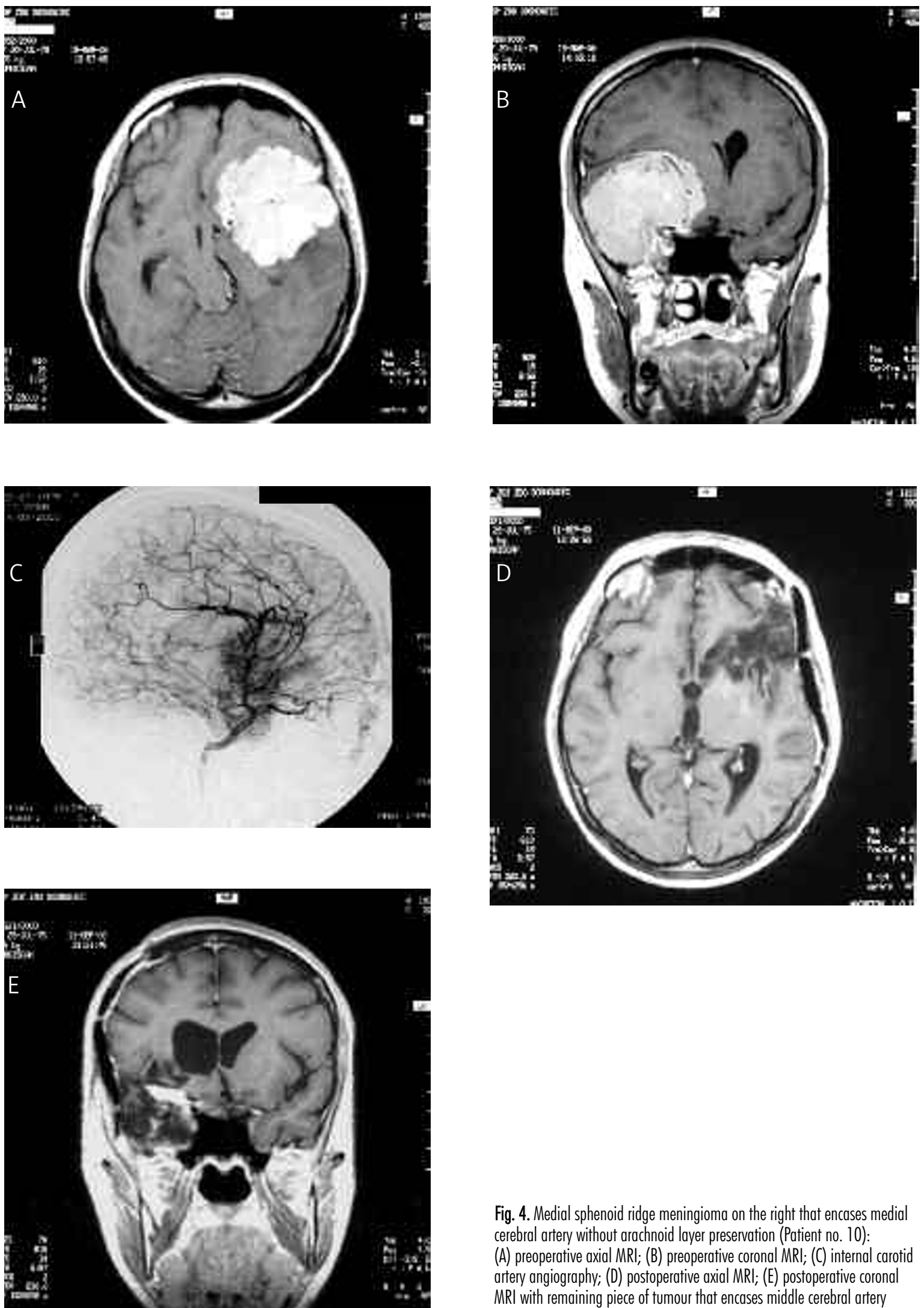

Fig. 4. Medial sphenoid ridge meningioma on the right that encases medial cerebral artery without arachnoid layer preservation (Patient no. 10):

(A) preoperative axial MRI; (B) preoperative coronal MRI; (C) internal carotid artery angiography; (D) postoperative axial MRI; $(\mathrm{E})$ postoperative coronal MRI with remaining piece of tumour that encases middle cerebral artery 
still group III meningiomas do not retain an arachnoid layer around the optic nerve. In our opinion, especially in the case of large tumours that develop over a long period of time, it is questionable which surface of the anterior clinoid process gave rise to the tumour. Al-Mefty's classification has been questioned by others $[6,9,12]$. In the majority of tumours, the arachnoid layer around large vessels and the optic nerve is preserved. These tumours are classified as group II, the predominant one in Al-Mefty's cohort. Al-Mefty reported only three cases in group I; in our group we had one relevant case. The question arises, however, how one can reconcile Al-Mefty's ideas with intraoperative observations in one of our patients who had the M1 part of the middle cerebral artery completely covered with tumour without any arachnoid layer present while the entire internal carotid artery retained this layer. The report of Russell and Benjamin [6] provides some clues. According to them, cerebrospinal fluid circulation around arachnoid-covered vessels diminishes while tumour pressure increases, which in turn results in the fusion of the arachnoid layer with tumour tissue. It is of particular importance then to distinguish early enough whether a given vessel lacks an arachnoid layer and not to force radical resection. A meticulous review of imaging studies, mainly angiography, is of value. Several years of follow-up suggests that tumour miscellanies on large vessels rarely give a base for recurrence. The report of Russell and Benjamin [6] concurs with this opinion. On top of that, it is worth mentioning that radiosurgery provides a valuable treatment modality for non-radical resections. Its usefulness is limited by the proximity of the visual tract, however [3]. Whenever subtotal resection with subsequent radiosurgery is premeditated it is crucial to create a free space margin between tumour remnants and visual tract structures. One should remember as well that tumour volume should not exceed $15 \mathrm{~cm}^{3}$ to be eligible for radiosurgery; in simple terms, all of the tumour measures should remain below $3 \mathrm{~cm}$ [13].

The aforesaid considerations of whether the arachnoid layer is present around large vessels are not relevant for recurrent cases [11]. Recurrence is one of the main problems related to skull base meningiomas, including those treated via FTOZA [14-16]. A meningioma that had developed within any of the basal cisterns and was resected (probably non-radically) recurs with no anato mical barriers to influence its growth. Its dissection from vascular as well as neural structures might be very difficult then. A good example is provided by the patient in whom in the second operation it proved impossible to preserve the optic nerve and the internal carotid artery wall (in spite of the fact that it was dissected from the tumour) was so weak that the blood stream ruptured it and forced a reconstruction of the vessel.

Preservation of large vessels is a primary goal of surgery in tumours that qualify for resection with FTOZA use. Of particular importance is identification of the middle cerebral artery prior to tumour resection $[3,6,17,18]$. It is hard to imagine a tumour in the central part of the middle cranial fossa that would render it impossible. The crucial factor is the determination of the surgeon in his exploration of lateral, i.e. insular, parts of the lateral fissure. Simultaneous separation of large vessels, first the middle cerebral artery and next the internal carotid artery, followed by tumour resection increases patient safety and speeds up the surgery.

Abdel Aziz et al. [1] pointed out that middle sphenoid ridge meningiomas can expand into the cavernous sinus. They divided such meningiomas into clinocavernous, spheno-cavernous and spheno-clinocavernous. Sekhar et al. [19] also used the term sphenocavernous meningiomas. Nakamura et al. [5] divided middle sphenoid ridge meningiomas into those invading and not invading the cavernous sinus.

In our opinion, the meningiomas described above should be divided into three groups based on their relationship to the cavernous sinus. The first group takes in tumours without any relationship to the cavernous sinus. The second group encompasses tumours with an attachment that involves the medial part of the lesser sphenoid wing and lateral wall of the cavernous sinus. The third group includes tumours that grow into the cavernous sinus. A separate group consists of tumours that do not grow into the cavernous sinus but have an attachment on the lateral wall of the cavernous sinus which does not expand on the medial part of the lesser sphenoid wing. They cannot be described as tumours or meningiomas of the lateral wall of the cavernous sinus. The term 'tumour of the lateral wall of the cavernous sinus' was lawfully reserved by El-Kalliny et al. [20] for tumours that grow in between the layers of the lateral wall of the cavernous sinus, such as trigeminal neurinomas. The tumours discussed above could be described as 'tumours of the anterior petroclinoid fold'. A characteristic feature of these tumours is their expansion toward the parabasal-medial part of the temporal lobe. FTOZA use in the resection of these tumours might reduce temporal lobe retraction then.

Separation of tumours with an attachment on the lateral wall of the cavernous sinus has a practical value. 
Their vasculature might arise from intracavernous branches of the internal carotid artery. The injury of such a branch or the internal carotid artery itself during coagulation of the tumour attachment was the most probable cause of the fatal haemorrhage two days after surgery that was seen in one of our patients. The authors base their therapeutic decisions on the clinical presentation of patients with tumours penetrating the cavernous sinus. If symptoms of cavernous sinus invasion had been seen preoperatively the cavernous sinus was opened in an attempt to achieve radical resection. If none of these symptoms had been present preoperatively, the resection would cease on the lateral wall of the sinus. These patients subsequently are under constant surveillance with follow-up MRI semi-annually. The presence of either clinical or radiological signs of cavernous sinus invasion gives a basis for reoperation or radiosurgery.

The most common complications of the resections of tumours that require FTOZA use described in the literature are hemiparesis and cranial nerve disturbances $[8,11]$. Our results corroborate the reports of others. By the end of postoperative rehabilitation, cranial nerve disturbances and hemiparesis were present in $20.5 \%$ and $27.5 \%$ of cases, respectively. Hemiparesis usually followed the surgery of large tumours with volumes exceeding $70 \mathrm{~cm}^{3}$. Cranial nerve deficits, particularly those responsible for eye movements, were present following the cases with cavernous sinus infiltration. One of the aims of treatment of tumours of the middle cranial base is visual acuity improvement $[12,21]$. In our cohort preoperative visual acuity disturbances were present in $27.5 \%$ of cases. Immediately after surgery they diminished to $17.2 \%$, with the final outcome at $13.7 \%$. One of the important factors that influence final outcome is embolization of highly vascular tumours. Day [2] stresses that reduced intraoperative bleeding creates convenient circumstances for identification and preservation of valid anatomical structures. Nevertheless, this opinion is disputable, as stated by Dolenc [22] in his comments for the report.

Tables 1 and 2 present the entire neurological status of the group analysed. Table 1 describes tumour-related symptoms and signs at presentation as well as their relationship to the surgery in time. It enables comparative analysis before treatment, at the end of the perioperative period when a number of symptoms deteriorate, and after rehabilitation, i.e. no earlier than six months after surgery. The first conclusion that arises from analysis of Table 1 is that the surgical modalities described above do not worsen disease-related symp- toms or cause transient deterioration only in the perioperative period. The other conclusion relates to the possible improvements of selected symptoms which occurred prior to surgery, particularly following longterm rehabilitation. Table 2 depicts iatrogenic sequelae of the treatment. Similarly to Table 1, the assessments were executed prior to surgery, immediately after and at the end of rehabilitation. There are no major differences between the first and the second assessment. Visible disparities are present between the second and the third evaluations. Most of the iatrogenic symptoms either decrease or disappear after rehabilitation.

The majority of patients in our group reported for treatment at the peak of their life activities and most of them resumed their normal life afterwards.

\section{Conclusions}

1. The fronto-temporo-orbito-zygomatic approach enables the removal of tumours that invade the interpeduncular fossa from the central part of the middle cranial fossa and adjacent anatomical regions without excessive brain retraction. The effectiveness of resection with this approach diminishes with tumour extension along the clivus toward the posterior fossa.

2. Surgical treatment of tumours that qualify for fronto-temporo-orbito-zygomatic approach use generally do not worsen pre-existing neurological symptoms, while side-effects of it either decrease or disappear with time.

3. The fronto-temporo-orbito-zygomatic approach facilitates good cosmetic outcome and does not impair eye functions on the treated side.

\section{Disclosure}

Authors report no conflict of interest.

\section{References}

1. Abdel Aziz K., Froelich S., Dagnew E., et al. Large sphenoid wing meningiomas involving the cavernous sinus: conservative surgical strategies for better functional outcomes. Newrosurgery 2004; 54: 1375-1384.

2. Day J. Cranial base surgical techniques for large sphenocavernous meningiomas: technical note. Neurosurgery 2000; 46: 754-760.

3. Margalit N., Lesser J., Moche J., et al. Meningiomas involving the optic nerve: technical aspects and outcomes for a series of 50 patients. Neurosurgery 2003; 53: 523-533. 
4. Al-Mefty O., Ayoubi S. Clinoidal meningiomas. Acta Neurochir Suppl 1991; 53: 92-97.

5. Nakamura M., Roser F., Jacobs C., et al. Medial sphenoid wing meningiomas: clinical outcome and recurrence rate. Neurosurgery 2006; 58: 626-639.

6. Russell S.M., Benjamin V. Medial sphenoid ridge meningiomas: classification, microsurgical anatomy, operative nuances, and long-term surgical outcome in 35 consecutive patients. Neurosurgery 2008; 62 [ONS suppl 1]: ONS38-ONS50.

7. Samii M., Tatagiba M. Surgical management of clinoidal meningiomas (comment). Neurosurgery 2001; 48: 1020.

8. Samii M., Tatagiba M., Monteiro M. Meningiomas involving the parasellar region. Acta Neurochir Suppl 1996; 65: 63-65.

9. Kaye A.H. Surgical management of clinoidal meningiomas. Neurosurgery 2001; 48: 1019-1020.

10. Santoro A., Salvati M., Vangelista T., et al. Fronto-temporoorbito-zygomatic approach and variant. Surgical technique and indication. J Neurosurg Sci 2003; 47: 141-147.

11. Al-Mefty O. Clinoidal meningiomas. J Neurosurg 1990; 73: 840849 .

12. Lee J.H., Sin-Soo J., Evans J., et al. Surgical management of clinoidal meningiomas. Neurosurgery 2001; 48: 1012-1021.

13. Lee J.Y., Nirarjan A., McInerney J., et al. Stereotactic radiosurgery providing long-term tumor control of cavernous sinus meningiomas. J Neurosurg 2002; 97: 65-72.

14. DeMonte F., Smith H.K., Al-Mefty O. Outcome of aggressive removal of cavernous sinus meningiomas. J Neurosurg 1994; 81: 245-251.

15. Mathiesen T., Lindquist C., Kilstrom L., et al. Recurrence of cranial base meningioma. Neurosurgery 1996; 39: 2-9.

16. Mirimanoff R.O., Dosoretz D.E., Linggood R.M., et al. Meningioma: analysis of recurrence and progression following neurosurgical resection. $J$ Neurosurg 1985; 62: 18-24.

17. DeMonte F. Surgical treatment of anterior basal meningiomas. J Neurooncol 1996; 29: 239-248.

18. Samii M., Ammirati M. Medial sphenoid wing meningiomas. In: Surgery of skull base meningiomas. Springer-Verlag, Berlin 1993, pp. 35-41.

19. Sekhar L., Ross D., Sen Ch. Cavernous sinus and sphenocavernous neoplasm. In: Surgery of cranial base tumors. Sekhar L., Janecka I. Raven Press, New York 1993, pp. 521-604.

20. El-Kalliny M., van Loveren H., Keller J., et al. Tumors of the lateral wall of the cavernous sinus. J Neurosurg 1992; 77: 508 514.

21. Risi P., Uske A., de Tribolet N. Meningioma involving the anterior clinoid process. Br J Neurosurg 1994; 8: 295-305.

22. Dolenc V. Cranial base surgical techniques for large sphenocavernous meningiomas: technical note (comment). Neurosurgery 2000; 46: 760 